\title{
AquaCrop Calibration and Validation for Faba Bean (Vicia faba L.) under Different Agronomic Managements
}

\author{
Ketema Tilahun Zeleke ${ }^{1,2}$ \\ 1 School of Agricultural and Wine Sciences, Charles Sturt University, Wagga Wagga, NSW 2650, Australia; \\ kzeleke@csu.edu.au; Tel.: +61-2-69334998 \\ 2 EH Graham Centre for Agricultural Innovation, Wagga Wagga, NSW 2650, Australia
}

Received: 17 May 2019; Accepted: 16 June 2019; Published: 18 June 2019

\begin{abstract}
Faba bean (Vicia faba L.) is an important pulse crop known for its nitrogen-fixing characteristics and as a disease-break crop in crop rotations. Sowing time, scheduling of supplemental irrigation, and sowing rate are some of the agronomic managements which affect faba bean growth and yield. The effect of these on faba bean yield can be evaluated using calibrated models. The Food and Agriculture Organization (FAO) AquaCrop model was calibrated and tested using two-year experimental data of different watering regimes, sowing dates, and sowing rates in a semiarid environment of South-Eastern Australia. AquaCrop adequately simulated the green canopy cover (CC), biomass development, grain yield, and soil water dynamics under different agronomic management conditions. AquaCrop simulated faba bean yield with 3\% deviation, root mean square error (RMSE) of $0.49 \mathrm{t} \mathrm{ha}^{-1}$, normalised root mean square error (NRMSE) of $12.4 \%$, index of agreement (d) of 0.95 , and $\mathrm{R}^{2}$ of 0.86 . The CC was simulated with RMSE of $14.1 \%, \mathrm{R}^{2}$ of 0.85 , and $d$ of 0.90 . The above-ground dry matter was predicted with RMSE of $2.6 \mathrm{t} \mathrm{ha}^{-1}, \mathrm{R}^{2}$ of 0.95 , and $d$ of 0.93 . Except for end-of-season values, the total soil water was also adequately simulated at RMSE of $21 \mathrm{~mm}, \mathrm{R}^{2}$ of 0.89 , and $d$ of 0.87 . The response of faba bean to supplemental irrigation, sowing time, and sowing rate was adequately simulated by the calibrated model. AquaCrop is a valuable decision support tool for predicting faba bean growth, yield, and soil water dynamics under different agronomic managements.
\end{abstract}

Keywords: crop modelling; soil water; South-Eastern Australia; sowing time; sowing rate; supplemental irrigation

\section{Introduction}

Faba bean is a major legume crop in many regions of the world. Australia is one of the major exporters of faba bean with average export of $307,000 \mathrm{t}$ with about $70 \%$ of this grown in the southern region of the country [1]. Agronomically, faba bean is useful for nitrogen fixation and as a disease break-crop in crop rotations [2,3]. Its yield is affected by the genetics of the cultivar, growing environment, and agronomic management. Management of limited-irrigation water for supplemental-irrigated faba beans, sowing time, and sowing rate are some of the management decisions which affect its growth and yield [4-6]. The decision to grow early or late season cultivars depends on the seasonal conditions such as soil moisture availability for timely sowing and potential heat and moisture stresses during the reproductive stage [7]. Although it is mainly cultivated under dryland/rainfed environments, faba bean responds well to irrigated or high rainfall environments. Therefore, when water is available and stable year-to-year production is required, supplemental irrigation can be applied in otherwise rainfed system. However, in arid and semiarid environments, optimising the available water resources for irrigation is of paramount importance. For this, it is important to know the critical times at which irrigation needs to be applied for optimum production. 
The time of sowing determines the relative growth of vegetative and reproductive parts and exposure to heat and moisture stresses. Early sown crops develop the necessary biomass in autumn while the temperature is still high [8]. However, early sown faba bean can be affected by disease pressure and lodging, especially in irrigated or high rainfall environments. On the other hand, if faba bean is sown late, the reproductive stage can be exposed to environmental stresses, such as heat and moisture stresses, and there will not be enough biomass, pod forming nods, and short plants which are difficult to harvest [9]. Sowing time depends also on the type of crop cultivar. Late flowering/long season cultivars need to be sown early, while early flowering/short season cultivars are sown late in order to escape frost and cold temperature during the flowering stage [10]. In dryland environments, the timing of sowing is determined by the availability of rainfall for seed germination and early plant growth. There are some reported evidences which show that increasing plant density increases yield, especially for a late sown crop [1]. This is due to the fact that late sown crops will not have enough time and resource to develop enough crop biomass unless this is compensated by increasing sowing density while early sown crops, even at a lower density, will have the required environmental conditions to develop enough biomass and compensate for low plant density.

The effects of supplemental irrigation, sowing time, and sowing rate on plant growth and yield can be studied using field experiments and/or computer simulation models. Several crop growth simulation models of different complexities have been developed and applied to simulate faba bean growth and yield: APSIM [11], DSSAT [12], STICS [13], ALAMEDA [14], CROPGRO [15,16]. The water-driven Food and Agriculture Organization (FAO) model, AquaCrop [17], is a user-friendly model with a relatively small number and readily available input data without compromising accuracy and robustness. AquaCrop has four modules: crop, soil, atmosphere, and management. The management component (e.g., irrigation, fertiliser, sowing time, sowing rate) is where the farmer or agronomist can make changes which can improve yield and productivity. However, in order to use AquaCrop to assess genotype $\times$ environment $\times$ management interactions and as a decision support tool, first it has to be calibrated and validated for a given crop species. AquaCrop has been calibrated, validated, and applied to study the effects of climate and agronomic managements on yield and productivity of several crops, including millet [18], winter wheat [19], leafy vegetables [20], cotton [21], maize [22], barley [23], and canola [24]. However, AquaCrop is not yet calibrated and validated for simulating growth, yield, and soil water dynamics of faba bean under different agronomic managements. Even in these reported studies for other crops, only very limited studies tested AquaCrop performance for sowing date and sowing density analysis. The objectives of this study are to: (1) Calibrate and validate AquaCrop for simulating green canopy cover (CC), above-ground dry matter (AGDM), yield and soil water dynamics; (2) assess the impacts of sowing dates, sowing rates, and supplemental irrigation strategies on faba bean growth, yield, and water productivity.

\section{Materials and Methods}

\subsection{The Field Experimental Site}

The experiment was conducted at Wagga Wagga in the Riverina region of South-Eastern Australia during the winter crop growing seasons of 2017 and 2018. The soil of the experimental site is a well-drained sandy loam Red Kandosol, the physico-chemical properties of which are presented in Table 1. The experimental area consisted of 24 experimental plots. Between the experimental plots, there were buffer plots to separate the experimental plots physically and hydrologically. Neutron probe access tubes were installed at the centre of each experimental plot. Soil water was measured using neutron moisture meter at 15, 30, 45, 30, 60, 90, and $120 \mathrm{~cm}$ depths at a fortnightly interval, on average. The neutron probe was already calibrated at a nearby site using simultaneous measurement of gravimetric soil moisture content and neutron probe reading to a depth of $120 \mathrm{~cm}$ [24]. Irrigation was applied using drip irrigation. Four drip laterals were laid per plot. Drippers, each with $1.6 \mathrm{~L} \mathrm{~h}^{-1}$ discharge, were spaced $30 \mathrm{~cm}$ along the laterals. 
Gypsum blocks were used to monitor soil water suction. In one of the replications of each treatment, gypsum blocks were installed at 15,45 , and $75 \mathrm{~cm}$ depths and $20 \mathrm{~cm}$ radius from the neutron probe access tubes. The data logger collected the data every $30 \mathrm{~min}$, wirelessly transferred to a central hub, and relayed to the web from which they were accessed and downloaded wherever there was internet access.

Table 1. Characteristics of the Red Kandosol soil at Wagga Wagga, Australia [25]. The soil chemical characteristics were measured during this study.

\begin{tabular}{cccccccc}
\hline $\begin{array}{c}\text { Soil Depth } \\
(\mathbf{c m})\end{array}$ & $\begin{array}{c}\boldsymbol{\rho}_{\mathbf{b}} \\
\left(\mathrm{g} \mathrm{cm}^{-3}\right)\end{array}$ & $\begin{array}{c}\text { LL15 } \\
\left(\mathbf{c m}^{\mathbf{3}} \mathbf{c m}^{-3}\right)\end{array}$ & $\begin{array}{c}\text { DUL } \\
\left(\mathbf{c m}^{\mathbf{3}} \mathbf{c m}^{-3}\right)\end{array}$ & $\begin{array}{c}\text { Sat } \\
\left(\mathbf{c m}^{\mathbf{3}} \mathbf{c m}^{-3}\right)\end{array}$ & $\begin{array}{c}\text { ECe } \\
\left(\mu \mathbf{c m}^{-1}\right)\end{array}$ & PH (unit) & OrgC (\%) \\
\hline $0-15$ & 1.48 & 0.11 & 0.29 & 0.35 & 42 & 7.6 & 1.22 \\
$15-30$ & 1.50 & 0.13 & 0.27 & 0.34 & 44 & 7.4 & 0.72 \\
$30-45$ & 1.45 & 0.15 & 0.25 & 0.32 & 43 & 7.4 & 0.35 \\
$45-60$ & 1.37 & 0.15 & 0.28 & 0.36 & 69 & 6.7 & 0.37 \\
$60-90$ & 1.43 & 0.15 & 0.29 & 0.35 & & & \\
$90-120$ & 1.55 & 0.15 & 0.31 & 0.34 & & & \\
\hline
\end{tabular}

$\rho_{\mathrm{b}}$ is bulk density, LL15 is the soil water content at 15 bar pressure, DUL (drainable upper limit) is the soil water content at field capacity, Sat is soil water content at saturation, ECe is Electrical conductivity of the 1:5 (soil/water) solution, $\mathrm{OrgC}$ is organic carbon.

\subsection{Experimental Treatments}

In the first year (2017), two sowing dates and four watering regime treatments were implemented. The sowing dates were 22 April and 20 May, designated as SD1 and SD2, respectively. The sowing date/watering regime combinations for the first sowing date were: No irrigation (100), irrigation during the vegetative stage (110), irrigation during the reproductive stage (101), and applying supplemental irrigation during all the stages when needed (111). For sowing date 2, these treatments were designated as $200,210,201$, and 211 , respectively. The sowing rate was done to get a target population of 24 plants $\mathrm{m}^{-2}$. In the second year there were two sowing date, two watering regime and two sowing rate treatments. The sowing dates were 21 April and 26 May, designated as SD1 and SD2, respectively. The sowing rates were set to get the target populations of 21 plants $\mathrm{m}^{-2}(\mathrm{~L})$ and 39 plants $\mathrm{m}^{-2}(\mathrm{H})$. The watering regimes were: Not irrigated $(\mathrm{R})$ and supplemental irrigation when needed (I). As a result, the treatments for the sowing date $1(\mathrm{SD} 1)$ were $1 \mathrm{RH}, 1 \mathrm{RL}, 1 \mathrm{IH}, 1 \mathrm{IL}$ and $2 \mathrm{RH}, 2 \mathrm{RL}, 2 \mathrm{IH}, 2 \mathrm{IL}$ for sowing date 2 (SD2).

\subsection{Crop Data}

The faba bean cultivar used for the experiment was cv. Samira, the highest-yielding, mid-flowering, mid-maturing, most widely grown variety in the region [26]. It is particularly responsive to high yielding situations and long-season environments. It has excellent disease resistance. Due to its late flowering, it can take advantage of late rainfall in longer season environments. In the first year the seeds were sown at two rows per plot and $60 \mathrm{~cm}$ row spacing. In the second year, there were two rows per plot at $60 \mathrm{~cm}$ spacing for 21 plants $\mathrm{m}^{-2}$ treatment and three rows per plot at $40 \mathrm{~cm}$ spacing for the 39 plants $\mathrm{m}^{-2}$ treatment. At the time of sowing, single-phosphate (0-9-0-11) was applied at a rate of $20 \mathrm{~kg} \mathrm{P} \mathrm{ha}^{-1}$. Due to the relatively dry season, use of drip irrigation, and the site with no history of cropping, there was no disease pressure.

The normalized difference vegetative index (NDVI) was measured using a hand-held GreenSeeker ${ }^{\circledR}$ (NTech Industries Inc., Ukiah, CA, USA). With NDVI measurement from different optical sensors and a range of plot level canopy cover measurements, Perry et al. [27] observed a linear relationship with $\mathrm{R}^{2}$ of 0.71 and standard error of 0.12 . As a result, NDVI can be used as a proxy for green canopy cover. For AGDM determination, five plants were cut from the buffer plots. The plant samples were dried for $48 \mathrm{~h}$ at $70{ }^{\circ} \mathrm{C}$. In 2017, the harvest dates were 8 November and 15 November for SD1 and SD2, respectively. In 2018, these were 2 November and 5 November, respectively. The harvest was done from the central $2 \mathrm{~m}$ length of each plot by cutting the plants at the ground level and drying it in an 
oven for $48 \mathrm{~h}$ at $70{ }^{\circ} \mathrm{C}$ to determine the AGDM. A threshing machine was used to separate the grain from the thrash.

\subsection{Weather Data}

The long-term average for the major weather parameters is shown in Figure 1. The average historical annual rainfall and evapotranspiration of Wagga Wagga are $526 \mathrm{~mm}$ and $1446 \mathrm{~mm}$, respectively, and minimum and maximum temperatures are $9{ }^{\circ} \mathrm{C}$ and $22{ }^{\circ} \mathrm{C}$, respectively. The annual rainfall distribution is more or less uniform, with winter months receiving only slightly higher rainfall. The crop water demand increases at the end of winter and in spring. The long-term average rainfall during winter crop growing season at Wagga Wagga (April-October) is $330 \mathrm{~mm}$. The seasons during which these experiments were conducted were considered to be the driest seasons, with a crop growing season of only $167 \mathrm{~mm}$ (51\% of the historical average) in 2017 and $161 \mathrm{~mm}$ (49\% of the historical average) in 2018.

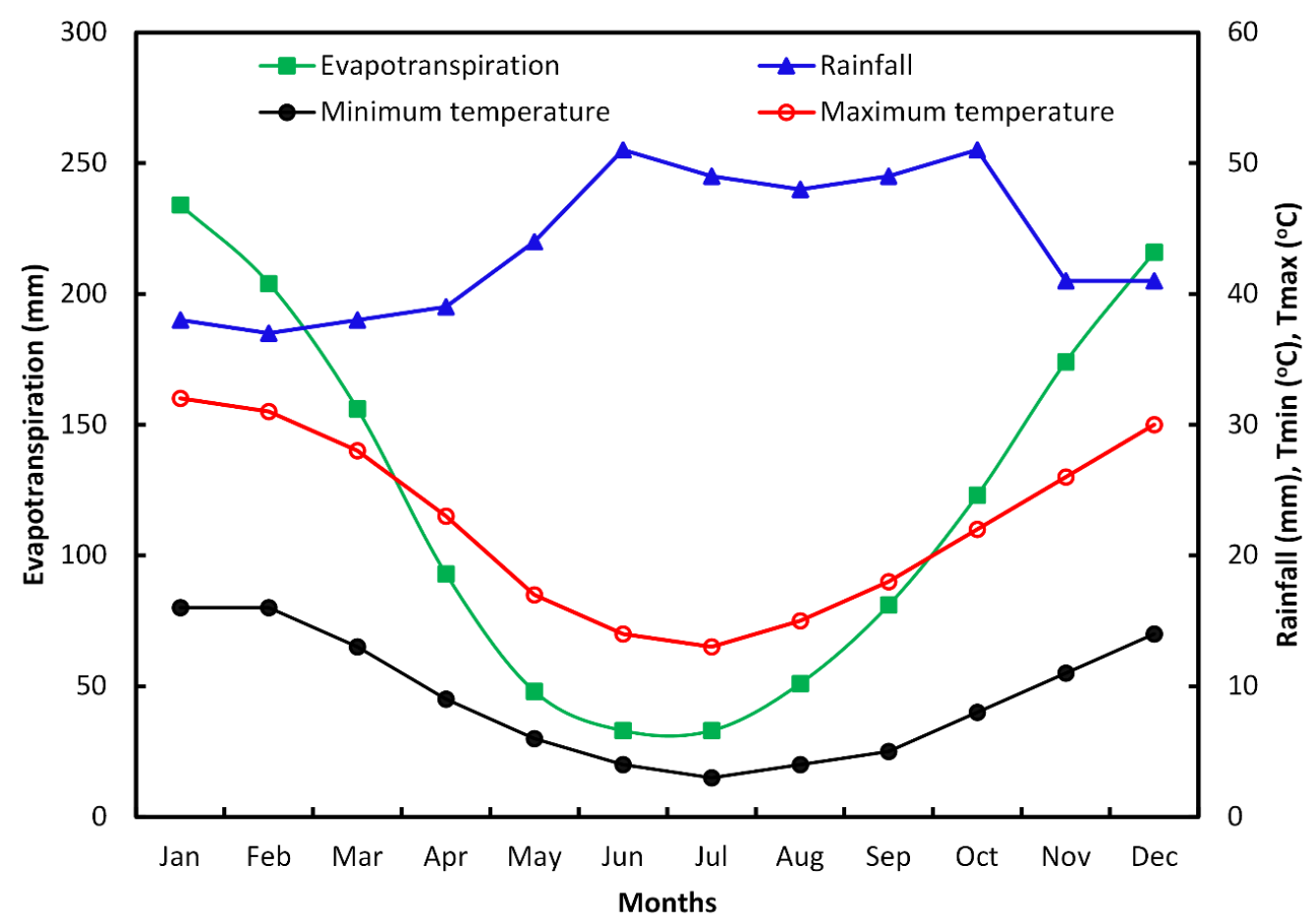

Figure 1. Average historical weather data (rainfall, temperature, and evapotranspiration) for Wagga Wagga, NSW, Australia (1989-2018).

\subsection{Brief Description of AquaCrop}

AquaCrop is a water-driven crop growth model which simulates crop biomass growth as a linear function of transpiration through the water productivity function (WP), biomass per unit of water transpired. It simulates the green canopy cover CC and uses reference evapotranspiration ETo and the transpiration crop coefficient Kct to calculate transpiration from which AGDM is calculated. Then grain yield is calculated from the AGDM and harvest index [28]. The water productivity of the crop species normalised for both evaporative demand and atmospheric $\mathrm{CO} 2\left(\mathrm{WP}^{*}\right)$ is calculated as:

$$
B_{i}=W P^{*}\left(\frac{T r_{i}}{E T o_{i}}\right)
$$

where $T r_{i}$ is daily transpiration and $B_{i}$ is daily AGDM production. The effects of water deficit on the crop are expressed through stress response coefficients for: Leaf growth, stomatal conductance, canopy senescence, and pollination failure. Stress function are functions of the fractional depletion of the root 
zone total available water. The CC is used to separate evaporation from transpiration [17]. A more detailed description of the principles and operation of the model is available in $[17,28]$.

In this study, AquaCrop was calibrated and validated by comparing the simulated canopy development, biomass accumulation, grain yield, soil water content of faba bean against field measurements made under irrigated and rainfed conditions, and different sowing dates and sowing rates.

\subsection{AquaCrop Input Data}

\subsubsection{Crop Data}

AquaCrop crop files were created from field observations of crop development and phenology. These include sowing date; seedling canopy size; days to emergence, to maximum CC, to flowering, to senescence, and to maturity; duration of flowering; and maximum effective rooting depth. The CC was measured using green seeker and the AGDM was obtained by cutting five plants during the crop growing season. In the absence of measured values for crop data, model default values were used.

\subsubsection{Weather Data}

Daily values of minimum and maximum air temperatures, rainfall and ETo are the data required by AquaCrop. ETo was calculated using the procedure described in the FAO Irrigation and Drainage Paper 56 [29]. The weather data were obtained from the Scientific Information for Land Owners (SILO) database for Wagga Wagga Agricultural Institute located adjacent to the experimental site. The $\mathrm{CO}_{2}$ concentration at Mauna Loa Observatory, Hawaii, was used. The historical average values of the weather parameters are shown in Figure 1, while the rainfall and evapotranspiration during the experimental period is shown in Figure 2.

\subsubsection{Soil Data}

The soil profile properties file was created using data from the APSoil database for soil water content at saturation, drained upper limit and drained lower limit, and hydraulic conductivity [25]. The soil water content was measured using neutron moisture meter (Model 503DR; Campbell Pacific Nuclear (CPN), CA, USA) calibrated at the site in an earlier study [24].

\subsubsection{Management Decisions}

The amount of irrigation water applied and dates of irrigation during the experimental periods were used to create the AquaCrop irrigation files. Soil fertility was considered to be non-limiting, and there was no stubble cover during the season. The field management data from the fully-irrigated treatment in the first year were used for model calibration, while the other datasets were used for validation.

\subsection{Model Calibration and Testing}

During calibration, certain model parameters were adjusted to make the simulation results match the observed values. For some of the parameters not measured during the experiment, such as water-extraction pattern and average root-zone expansion, model default values were used. Observations of phenological stages of the crop ( $90 \%$ emergence, days to maximum CC, and days to harvest) were used in the calibration. The CC was calibrated first, followed by AGDM. Water productivity was derived from the well-watered field data and re-adjusted during consecutive simulations until a good fit between measured and simulated biomass was obtained. Similarly, fine-tunings and adjustments of other parameters were done until good matches between simulated and measured values of the respective variables were attained. Variables evaluated for goodness of fit of the model were CC, AGDM, total soil water (TSW), and grain yield. Once good fit was obtained 
for these variables, the calibrated model was subjected to validation using observed data from the other treatments.

Performance of AquaCrop in simulating CC, AGDM, soil water balance, and grain yield was evaluated by comparing simulated results against observed data. The statistical indices used in the validation were coefficient of determination $\left(\mathrm{R}^{2}\right)$, regression 1:1 line, absolute (RMSE) and normalized (NRMSE) root mean square error, and index of agreement ( $d$-index):

$$
\begin{gathered}
\text { RMSE }=\sqrt{\frac{1}{n} \sum_{i=1}^{n}\left(M_{i}-S_{i}\right)^{2}} \\
\text { NRMSE }=\frac{1}{n} \sqrt{\frac{1}{n} \sum_{i=1}^{n}\left(M_{i}-S_{i}\right)^{2}} \times 100 \\
d=1-\frac{\sum_{i=1}^{n}\left(S_{i}-M_{i}\right)^{2}}{\sum_{i=1}^{n}\left(\left|S_{i}-\bar{M}\right|+\left|M_{i}-\bar{M}\right|\right)^{2}}
\end{gathered}
$$

where $M_{i}$ and $S_{i}$ are the measured and simulated values, $\bar{M}$ is the average of the $\mathrm{M}_{\mathrm{i}}$ values, $n$ is the number of measurements done over the season.

As RMSE tends toward zero, model performance improves. The closer the index of agreement $d$-statistic value is to one, the better the agreement between measured and simulated values and vice versa [30]. The coefficient of determination $\mathrm{R}^{2}$ explains the amount of the variance explained by the model in comparison to the observed values. Its value ranges from 0 to 1 , with values close to 1 indicating a good model performance.

\section{Results and Discussion}

\subsection{Rainfall, Irrigation, Evapotranspiration and Soil Water}

Daily values of rainfall, irrigation, evapotranspiration, and total soil water (TSW) for the season used in the model calibration are shown in Figure 2. There was non-uniform rainfall distribution during the season, with most of the rain falling during the winter months and towards the end of the season. There was only limited amount of rainfall in the weeks after sowing and during the reproductive stage in early spring. Evapotranspiration was low during late autumn and winter months but was increasing during the spring period. The TSW did not significantly vary during the winter months. However, in response to the evapotranspiration increase, it started decreasing during early spring period. Irrigation was applied during this period to prevent crop water stress. Irrigation was stopped towards the end of the season as there was significant amount of rainfall. The amount of rainfall and irrigation for the different treatments in the first and second years of the experiment are shown in Table 2. 


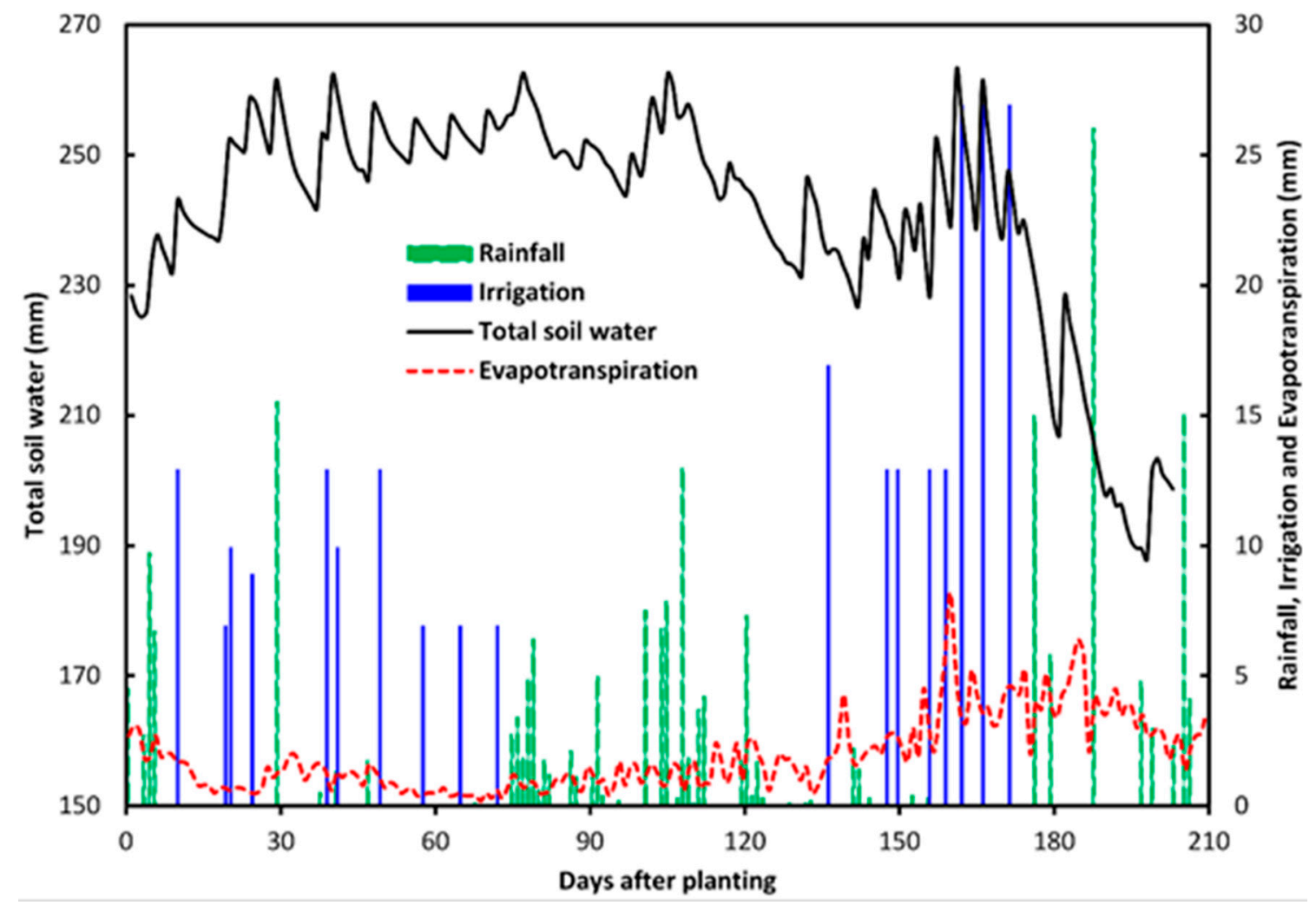

Figure 2. Rain, irrigation, evapotranspiration, and total soil water for the calibration treatment in 2017.

Table 2. Rainfall and irrigation data for the different treatments in the first and second years of the field experiment.

\begin{tabular}{ccc|ccc}
\hline \multirow{2}{*}{ Treatments } & \multicolumn{2}{c|}{ Year 1 } & \multirow{2}{*}{ Treatments } & \multicolumn{2}{c}{ Year 2 } \\
\cline { 2 - 3 } \cline { 2 - 3 } & Rainfall $(\mathbf{m m})$ & Irrigation $\mathbf{( m m})$ & & Rainfall $\mathbf{( m m})$ & Irrigation $(\mathbf{m m})$ \\
\hline 100 & 219 & 0 & $1 \mathrm{RL}$ & 149 & 0 \\
110 & 219 & 61 & $1 \mathrm{RH}$ & 149 & 0 \\
101 & 219 & 107 & $1 \mathrm{IL}$ & 149 & 250 \\
111 & 219 & 246 & $2 \mathrm{IH}$ & 149 & 250 \\
200 & 269 & 0 & $2 \mathrm{RH}$ & 165 & 0 \\
210 & 269 & 31 & $2 \mathrm{IL}$ & 165 & 0 \\
201 & 269 & 107 & $2 \mathrm{IH}$ & 165 & 187 \\
211 & 269 & 207 & 165 & 187 \\
\hline
\end{tabular}

\subsection{Calibration for Soil Water Content, Green Canopy Cover, Above-Ground Dry Matter and Yield}

The data from the treatment with non-limiting soil water regime, sown in the recommended sowing window, and at the recommended sowing rate were used to calibrate AquaCrop for the conservative parameters. The soil and crop parameters were iteratively adjusted until close agreement was achieved between the measured and simulated TSW, CC, AGDM, and grain yield. The agreement was measured using different statistical fitting parameters $\left(\mathrm{R}^{2}, d\right.$, RMSE, NRMSE). The fitting parameters for all the treatments and variables are presented in Table 3. Figure 3 shows the measured and simulated values of these variables and values of statistical fitting parameters. The fitting of the calibration data and model simulation was very good with statistical parameters as indicated: AGDM $\left(R^{2}=0.96, d=0.94\right.$, RMSE $\left.=3.1 \mathrm{tha}^{-1}\right), \mathrm{CC}\left(\mathrm{R}^{2}=0.83, d=0.96, \mathrm{RMSE}=11.9 \%\right), \mathrm{TSW}\left(\mathrm{R}^{2}=0.85, d=0.95, \mathrm{RMSE}=9.4 \mathrm{~mm}\right)$. The measured grain yield $\left(5.24 \mathrm{t} \mathrm{ha}^{-1}\right)$ was also correctly simulated $\left(5.14 \mathrm{t} \mathrm{ha}^{-1}\right)$ with deviation of only $2 \%$. 
Table 3. Statistical evaluation parameters and values for grain yield, total soil water, green canopy cover, and above-ground dry matter for calibration and validation treatments of faba bean in 2017 and 2018.

\begin{tabular}{|c|c|c|c|c|c|c|c|c|c|c|c|c|c|c|c|c|}
\hline \multirow[b]{2}{*}{ Year } & \multirow[b]{2}{*}{ Treatment } & \multicolumn{3}{|c|}{ Grain Yield $\left(t\right.$ ha $\left.^{-1}\right)$} & \multicolumn{4}{|c|}{ Total Soil Water (mm) } & \multicolumn{4}{|c|}{ Green Canopy Cover (\%) } & \multicolumn{4}{|c|}{ Above-Ground Dry Matter ( $\mathrm{tha}^{-1}$ ) } \\
\hline & & $M\left(t h a^{-1}\right)$ & $S\left(t h^{-1}\right)$ & $\begin{array}{l}\text { Dev } \\
(\%)\end{array}$ & $\mathbf{R}^{2}$ & d & $\begin{array}{l}\text { RMSE } \\
(\mathrm{mm})\end{array}$ & $\begin{array}{c}\text { NRMSE } \\
(\%)\end{array}$ & $\mathbf{R}^{2}$ & d & $\begin{array}{c}\text { RMSE } \\
(\%)\end{array}$ & $\begin{array}{c}\text { NRMSE } \\
(\%)\end{array}$ & $\mathbf{R}^{2}$ & d & RMSE & $\begin{array}{c}\text { NRMSE } \\
(\%)\end{array}$ \\
\hline 2017 & SD1-NI & 3.65 & 4.41 & 17 & 0.86 & 0.70 & 33.3 & 15.1 & 0.83 & 0.88 & 19.8 & 45.6 & 0.94 & 0.94 & 2.9 & 42.8 \\
\hline 2017 & SD1-RI & 5.85 & 5.55 & -5 & 0.83 & 0.86 & 16.5 & 7.3 & 0.88 & 0.94 & 15.1 & 29.8 & 0.96 & 0.88 & 4.7 & 56.6 \\
\hline 2017 & SD1-VI & 3.97 & 4.46 & 11 & 0.88 & 0.81 & 27.0 & 12.8 & 0.92 & 0.93 & 14.2 & 29.1 & 0.98 & 0.91 & 3.7 & 46.9 \\
\hline 2017 & SD1-FI & 5.24 & 5.14 & -2 & 0.85 & 0.95 & 9.4 & 4.1 & 0.83 & 0.96 & 11.9 & 21.8 & 0.96 & 0.94 & 3.1 & 40.1 \\
\hline 2017 & SD2-NI & 2.32 & 2.57 & 10 & 0.90 & 0.80 & 31.6 & 14.9 & 0.85 & 0.82 & 12.4 & 23.3 & 0.98 & 0.97 & 0.9 & 24.4 \\
\hline 2017 & SD2-RI & 5.24 & 4.92 & -7 & 0.79 & 0.79 & 28.1 & 12.3 & 0.90 & 0.93 & 17.2 & 52.2 & 0.94 & 0.96 & 1.4 & 30.1 \\
\hline 2017 & SD2-VI & 3.02 & 3.58 & 16 & 0.92 & 0.82 & 30.3 & 14.3 & 0.98 & 0.98 & 8.9 & 25.7 & 0.94 & 0.96 & 1.1 & 27.2 \\
\hline 2017 & SD2-FI & 5.52 & 5.20 & -6 & 0.92 & 0.93 & 15.3 & 6.6 & 0.98 & 0.97 & 12.4 & 33.7 & 0.92 & 0.91 & 2.3 & 43.2 \\
\hline 2018 & SD1-IH & 4.64 & 4.10 & -13 & 0.88 & 0.96 & 10.1 & 4.4 & 0.96 & 0.98 & 8.0 & 11.1 & 0.98 & 0.96 & 2.7 & 32.8 \\
\hline 2018 & SD1-IL & 4.89 & 4.10 & -11 & 0.92 & 0.91 & 14.1 & 6.3 & 0.94 & 0.91 & 9.9 & 13.5 & 0.96 & 0.94 & 3.4 & 40.6 \\
\hline 2018 & SD1-NIH & 3.23 & 3.27 & 1 & 0.98 & 0.90 & 21.3 & 9.8 & 0.88 & 0.84 & 13.4 & 18.3 & 0.88 & 0.87 & 4.9 & 55.9 \\
\hline 2018 & SD1-NIL & 3.15 & 3.27 & 4 & 0.98 & 0.94 & 17.9 & 8.2 & 0.85 & 0.83 & 13.4 & 18.9 & 0.92 & 0.92 & 3.7 & 45.9 \\
\hline 2018 & SD2-IH & 4.33 & 3.64 & -19 & 0.96 & 0.96 & 12.3 & 5.5 & 0.74 & 0.93 & 15.0 & 31.6 & 0.96 & 0.92 & 2.3 & 36.7 \\
\hline 2018 & SD2-IL & 4.18 & 4.00 & -4 & 0.92 & 0.94 & 15.4 & 6.7 & 0.92 & 0.92 & 16.5 & 31.3 & 0.96 & 0.95 & 1.6 & 27.3 \\
\hline 2018 & SD2-NIH & 2.04 & 1.69 & -21 & 0.81 & 0.83 & 29.9 & 16.1 & 0.52 & 0.74 & 21.8 & 47.5 & 0.92 & 0.97 & 0.8 & 19.2 \\
\hline 2018 & SD2-NIL & 2.08 & 1.73 & -20 & 0.85 & 0.78 & 26.8 & 10.5 & 0.66 & 0.84 & 15.7 & 39.6 & 0.92 & 0.85 & 2.7 & 45.8 \\
\hline \multirow{5}{*}{\multicolumn{2}{|c|}{ Average }} & 3.96 & 3.85 & -3 & 0.89 & 0.87 & 21.2 & 9.7 & 0.85 & 0.90 & 14.1 & 29.6 & 0.95 & 0.93 & 2.6 & 38.4 \\
\hline & & $\mathbf{R}^{2}$ & 0.86 & & & & & & & & & & & & & \\
\hline & & $d$ & 0.95 & & & & & & & & & & & & & \\
\hline & & RMSE & 0.49 & & & & & & & & & & & & & \\
\hline & & NRMSE & 12.4 & & & & & & & & & & & & & \\
\hline
\end{tabular}

(SD1-NI = sowing date 1, not irrigated; SD1-RI = sowing date 1, reproductive-stage irrigated; SD1-VI = sowing date 1, vegetative stage irrigated; SD1-FI = sowing date 1, fully irrigated; $\mathrm{SD} 2-\mathrm{NI}=$ sowing date 2, not irrigated; SD2-RI = sowing date 2, reproductive-stage irrigated; SD2-VI = sowing date 2, vegetative stage irrigated; SD2-FI = sowing date 2, fully irrigated; $\mathrm{SD} 1-\mathrm{IH}=$ sowing date 1 , irrigated, high sowing rate; SD1-IL = sowing date 1, irrigated, low sowing rate; SD1-NIH = sowing date 1, not irrigated, high sowing rate; SD1-NIL = sowing date 1 , not irrigated, low sowing rate; SD2-IH = sowing date 2, irrigated, high sowing rate; SD2-IL = sowing date 2, irrigated, low sowing rate; SD2-NIH = sowing date 2, not irrigated, high sowing rate; $\mathrm{SD} 2-\mathrm{NIL}=$ sowing date 2, not irrigated, low sowing rate); Dev = deviation; $\mathrm{M}=$ measured; $\mathrm{S}=$ simulated. 

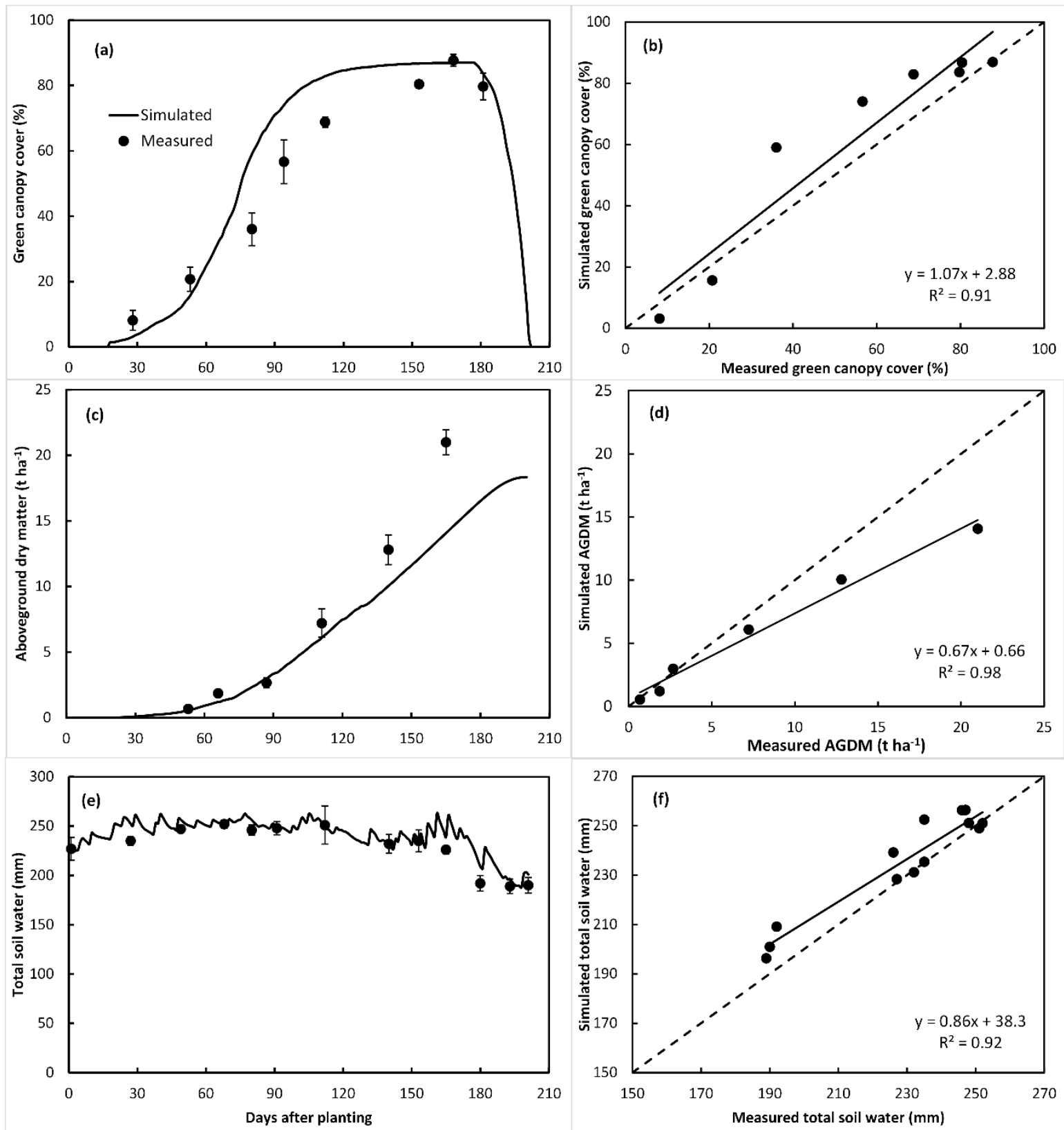

Figure 3. The evolution of measured and simulated values of crop canopy cover (CC), above-ground dry matter (AGDM), and total soil water (TSW) of $120 \mathrm{~cm}$ soil profile for the calibration treatment. Regression of measured data and simulated results and distribution of measured values about 1:1 line are also shown. (a) Measured and simulated CC during the growing season; (b) regression of measured and simulated CC; (c) measured and simulated AGDM during the growing season; (d) regression of measured and simulated AGDM; (e) measured and simulated TSW during the growing season; (f) regression of measured and simulated TSW.

Parameters determined using the calibration data are presented in Table 4. These parameters include canopy growth coefficient, canopy decline coefficient, normalised crop water productivity (WP*), and soil water depletion factors for canopy growth, transpiration, and leaf senescence. Conservative parameters are assumed to be applicable for different geographic locations, different cultivars, different soil moisture stress levels, and different management practices [28]. The WP* value of $18 \mathrm{~g} \mathrm{~m}^{-2}$ is in the range of the values for $\mathrm{C} 3$ crops $\left(13-18 \mathrm{~g} \mathrm{~m}^{-2}\right)$ [31]. 
Table 4. AquaCrop calibration parameters and their respective values for faba bean (cv. Samira).

\begin{tabular}{cc} 
Base temperature $\left({ }^{\circ} \mathrm{C}\right)$ & 0 \\
Upper temperature $\left({ }^{\circ} \mathrm{C}\right)$ & 30 \\
Cover per seedling $\left(\mathrm{cm}^{2}\right.$ plant $\left.^{-1}\right)$ & 5 \\
Canopy growth coefficient CGC $\left(\% \mathrm{GDD}^{-1}\right)$ & 0.701 \\
Canopy decline coefficient CDC $\left(\% \mathrm{GDD}^{-1}\right)$ & 0.697 \\
Soil water depletion factor for canopy expansion, upper limit & 0.25 \\
Soil water depletion factor for canopy expansion, lower limit & 0.65 \\
Shape factor for water stress coefficient for canopy expansion & 3.0 \\
Soil water depletion factor for stomatal closure & 0.5 \\
Shape factor for water stress coefficient for stomatal closure & 3.0 \\
Soil water depletion factor for early canopy senescence & 0.50 \\
Shape factor for water stress coefficient for canopy senescence & 4.0 \\
Normalized water productivity WP* $\left(\mathrm{g} \mathrm{m}^{-2}\right)$ & 18 \\
Adjustment for yield formation $(\%)$ & 100 \\
Initial canopy cover CCo (\%) & 1.2 \\
Maximum canopy cover CCx $(\%)$ & 90 \\
Time to maximum canopy cover $(\mathrm{GDD})$ & 1200 \\
Time to flowering (GDD) & 1290 \\
Length of the flowering stage (GDD) & 557 \\
Time to senescence (GDD) & 1845 \\
Time to maturity (GDD) & 2380 \\
Rooting depth (m) & 0.90 \\
Reference harvest index HIo $(\%)$ & 40 \\
\hline
\end{tabular}

\subsection{Validation}

The performance of AquaCrop in simulating soil water content, crop growth, and yield for different watering regimes, sowing times, and sowing rates was evaluated. The validation of the model was performed using the calibrated model and data from the other 15 treatments not used for calibration. The same crop parameters used in the calibration were used in the validation model. The statistical parameters obtained from the regression of measured and simulated values are presented in Table 3. The calibrated model was used to evaluate the effect of supplemental irrigation, sowing dates, and sowing rates on faba bean growth and yield.

\subsubsection{Total Soil Water}

The measured and simulated total soil (TSW) of all the treatments is plotted as shown in Figure 4. AquaCrop simulated the TSW with reasonable accuracy $\left(\mathrm{R}^{2}=0.89, d=0.87\right.$, RMSE of $\left.21 \mathrm{~mm}\right)$. The model underestimated the lower values, as indicated by a high slope of the regression equation, while the higher values were correctly simulated.

\subsubsection{Green Canopy Cover}

Figure 5 shows that AquaCrop has simulated the green canopy cover (CC) reasonably well with $\mathrm{R}^{2}=0.85, d=0.90, \mathrm{RMSE}=14.1 \%$. Accurate calibration for CC is important as it determines the transpiration rate, biomass production, and eventually the grain yield. Canopy expansion rate is calculated from the data on phenological stages, such as dates of emergence, maximum CC, senescence, and maturity. 


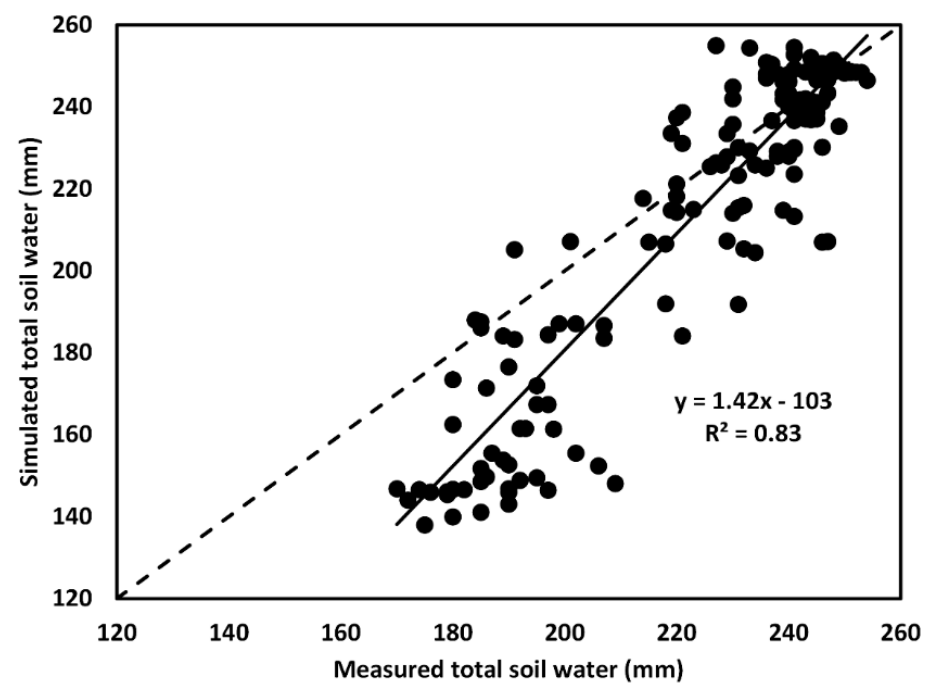

Figure 4. Measured and simulated total soil water (TSW) for all the treatments not used in the calibration for different sowing dates, sowing rates, and soil water regimes.

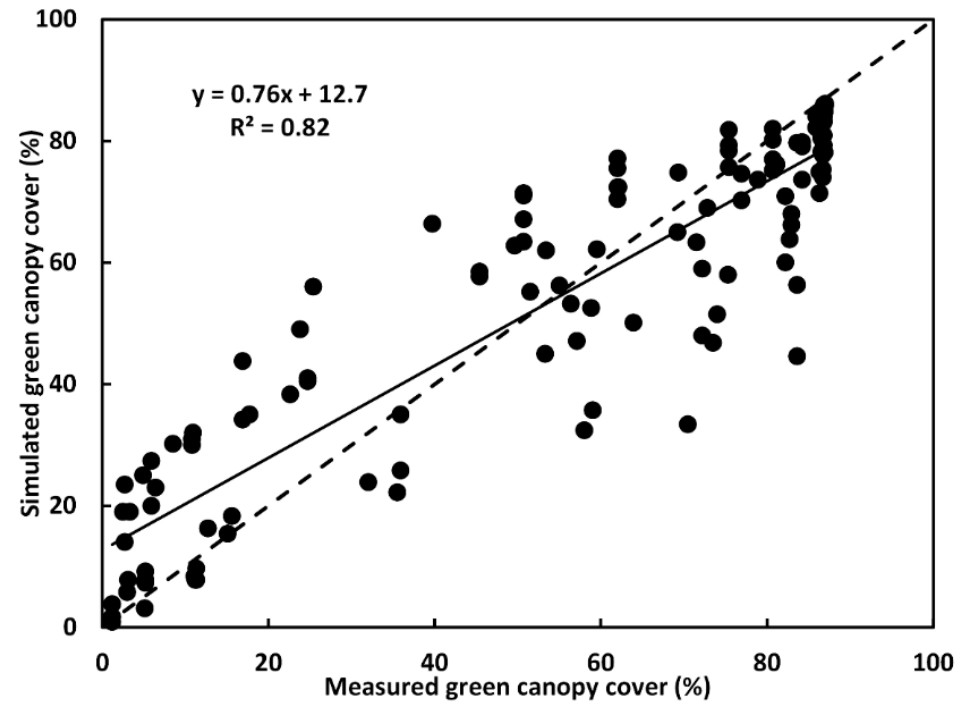

Figure 5. Measured and simulated green canopy cover (CC) for all the treatments not used in the calibration for different sowing dates, sowing rates, and soil water regimes.

\subsubsection{Above-Ground Dry Matter and Grain Yield}

As shown in Figure 6 and Table 3, except for slight underestimation of higher values, the AGDM was adequately simulated with $\mathrm{R}^{2}=0.95, d=0.93$, RMSE $=2.6 \mathrm{t} \mathrm{ha}^{-1}$ and close to unity slope. Figure 7 shows that AquaCrop has simulated the most important output, grain yield, with acceptable accuracy under varying environmental and management conditions with average deviation between simulated and observed yield of $3 \%$, RMSE $=0.49 \mathrm{tha}^{-1}, \mathrm{R}^{2}=0.86$, and $d=0.95$. AquaCrop explained $86 \%$ of the variation in yield. Figure 8 also shows that AquaCrop has adequately simulated the effect of irrigation. 


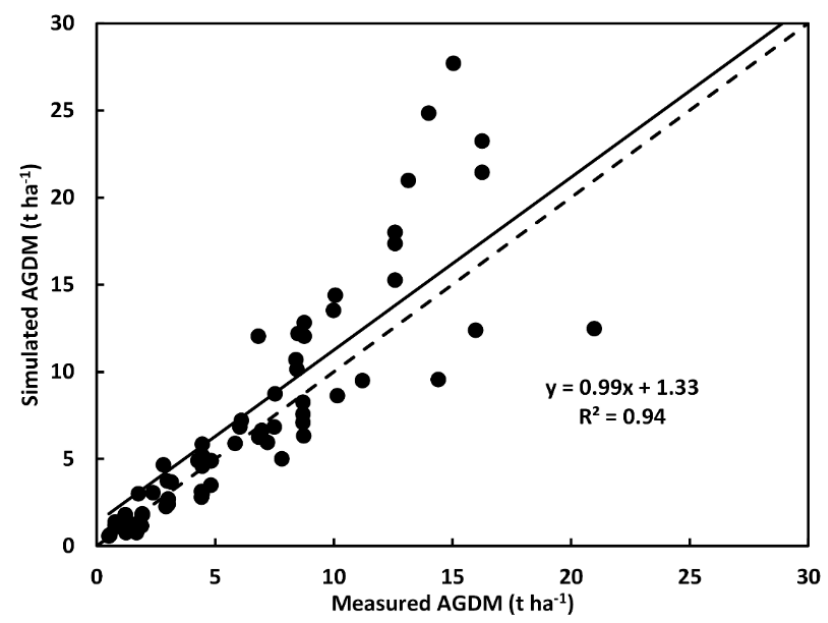

Figure 6. Measured and simulated above-ground dry matter (AGDM) for all the treatments not used in the calibration; different sowing dates, sowing rates, and soil water regimes.

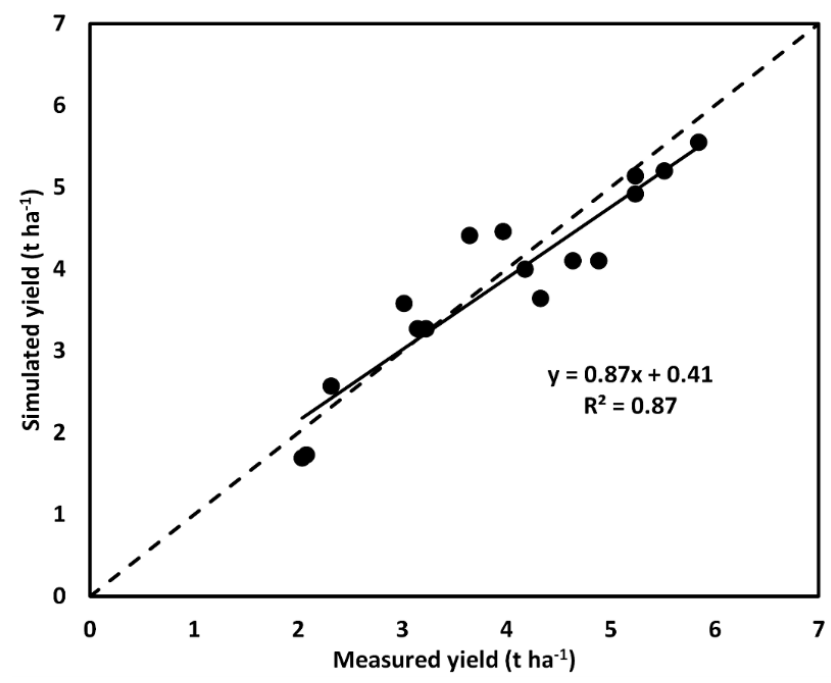

Figure 7. Measured and simulated yield of faba bean in 2017 and 2018 under different watering regimes, sowing dates, and sowing rates.

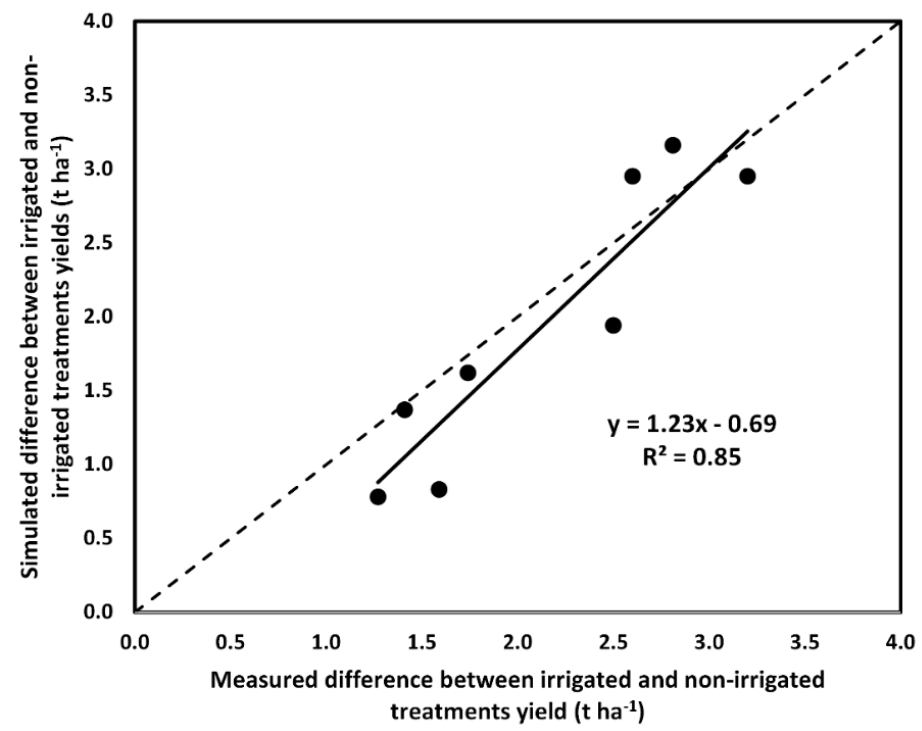

Figure 8. Relation between measured and simulated values of the difference between irrigated and non-irrigated treatments. 


\subsection{Effect of Sowing Date}

Correct sowing time allows extended flowering period and pod set and pod filling before moisture and heat stress period [32]. In South-Eastern Australia, the recommended sowing window for faba bean is from 20 April to 15 May [33]. Due to warmer temperature in autumn, early sown faba bean has improved early vigour and a much-developed canopy. If it is sown later than mid-May, the high temperature and moisture stress in spring affects flowering, pod-filling, and biomass growth. This results in fewer flowering nodes, reduced number and size of pods, and eventually low yields [34]. The short stature of late sown faba bean and pods formed close to the ground make machinery harvest difficult. Historically, sowing has been delayed to minimise the risks of disease, such as chocolate spot (Botrytis fabae). However, modern faba bean varieties have some degree of disease resistance, and sowing times for these varieties may not need to be delayed. In this study, the flowering period of faba bean sown in the fourth week of April was 9 August to 29 September, while the faba bean sown in the fourth week of May flowered during 5 September to 6 October.

AquaCrop calibrated for the faba bean sown in the optimum sowing window (on 21 April) was applied to simulate the effect of delayed sowing on crop growth, yield and soil water dynamics. Figure 9 shows measured and AquaCrop simulated CC, AGDM, and SW for the crop sown on 21 April and 26 May. AquaCrop accurately reflected the effects of sowing date on crop growth, grain yield, and soil water dynamics (Table 3 and Figure 9). Delayed sowing reduced the CC. Early sown faba bean reached the maximum canopy cover much earlier than the late sown faba bean. The maximum CC of the early sown faba bean was $80 \%$, and for the late sown faba bean it was about $60 \%$. The early sown faba bean was at the maximum CC for much longer (about 90 days), while the late sown faba bean was in that stage for only about 30 days. AquaCrop underestimated the CC during the early part of the late sown faba bean. AquaCrop has adequately simulated the effect of delayed sowing on the AGDM, although it tended to underestimate maximum AGDM both for early and late sown crops. The measured maximum AGDM was $24 \pm 1.12 \mathrm{t} \mathrm{ha}^{-1}$ and $12 \pm 0.83 \mathrm{tha}^{-1}$ for the early and late sown crops, respectively. The simulated maximum AGDM of the early sown crop was also much higher than the late sown crop. The AGDM was increasing even after the crop reached the maximum CC. However, the model underestimated the maximum AGDM under rainfed/water deficit conditions. Towards the end of the season, soil water was also slightly underestimated. The model also slightly underestimated early canopy growth, especially under irrigated conditions.

In 2017, for the first sowing date (21 April), the measured yield was $3.65 \mathrm{t} \mathrm{ha}^{-1}$, and the simulated yield was $4.41 \mathrm{tha}^{-1}$. For the second sowing date (26 May), these values were $2.32 \mathrm{t} \mathrm{ha}^{-1}$ and $2.57 \mathrm{t} \mathrm{ha} \mathrm{h}^{-1}$, respectively. The measured yield decrease due to delayed sowing was $36 \%$, while the simulated yield decrease was $42 \%$. In 2018, for the first sowing date, the average measured dryland yield was $3.15 \mathrm{t} \mathrm{ha}^{-1}$ while the simulated dryland yield was $3.27 \mathrm{tha}^{-1}$. For the second sowing date, these values were $2.08 \mathrm{t} \mathrm{ha}^{-1}$ and $1.73 \mathrm{tha}^{-1}$, respectively. The measured yield decrease due to delayed sowing was $34 \%$, while simulated yield decrease was $47 \%$. AquaCrop correctly simulated the effect of sowing date on faba bean yield, providing almost equivalent decrease in yield due to delayed sowing as the measured values. These values are similar to the ones reported by Richards et al. [32] for three trials sites in South-Eastern NSW: 25\% yield decline when sowing is delayed until 18 May instead of 1 May at Wagga Wagga, $45 \%$ yield decline when sowing is delayed until 6 May instead of 16 April at Junee Reefs, and 26\% yield decline when sowing is delayed until 13 May instead of 23 April at Lockhart. 

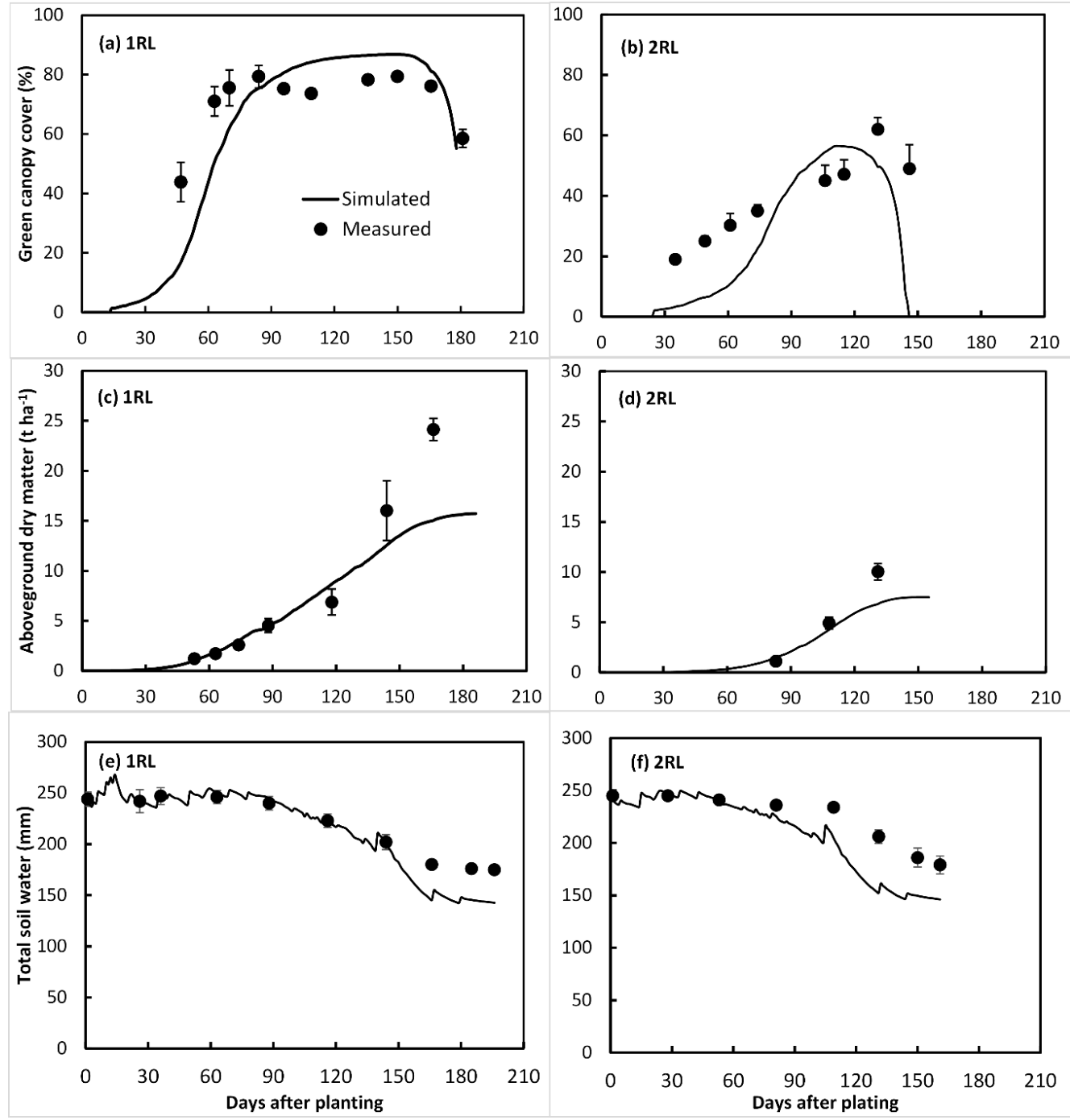

Figure 9. Measured and simulated green canopy cover (CC), above-ground dry matter (AGDM), and total soil water (TSW) for an early sown (1RL) and late sown (2RL) un-irrigated faba bean. 1RL stands for sowing date 1 (21 April), rainfed, low sowing rate (21 plants $\mathrm{m}^{-2}$ ); $2 \mathrm{RL}$ stands for sowing date 2 (26 May), rainfed, low sowing rate $\left(21\right.$ plants $\left.\mathrm{m}^{-2}\right)$. (a) Measured and simulated CC for 1RL; (b) measured and simulated CC for 2RL; (c) measured and simulated AGDM for 1RL; (d) measured and simulated AGDM for 2RL; (e) measured and simulated TSW for 1RL; (f) measured and simulated TSW for 2RL.

Figure 9e shows that AquaCrop adequately simulated the general trend of measured total soil water except for some differences towards the end of the season. Since the discrepancy is cumulative, the TSW was underestimated by a significant amount towards the end of the season. By the end of the season, the early sown crop exhausted the TSW more than the late sown crop, indicating a deeper rooting system. This pattern is similar to the one observed from the soil water tension data in Figure 10. Although there was still high soil moisture reserve at deeper depths, the late-sown crop was not able to extract this water even from the $45 \mathrm{~cm}$ depth. For the early sown faba bean, the soil water tension at $15 \mathrm{~cm}$ has reached $300 \mathrm{kPa}$ (the maximum recordable tension by the logger) by early September, and by mid-September the soil water tension at $45 \mathrm{~cm}$ and $75 \mathrm{~cm}$ depths has reached the $300 \mathrm{kPa}$. However, for the late-sown faba bean, the gypsum block at $15 \mathrm{~cm}$ depth reached $300 \mathrm{kPa}$ only at the beginning of October. Even by early November, the soil water tension was $91 \mathrm{kPa}$ and $69 \mathrm{kPa}$ at the $45 \mathrm{~cm}$ and $75 \mathrm{~cm}$ depths, respectively. Generally, due to their shallow root system, faba beans do not fully extract 
the soil water, potentially increasing the residual available water the next season crop. This shallow root system limits their ability to withstand dry conditions.

As shown in Figure 11, for both irrigated and non-irrigated treatments, the water productivity/water use efficiency is higher for early sown treatments. Treatments which were sown late and also not irrigated had the lowest water productivity. Irrigation of late sown crop improved the water productivity, $1.17 \mathrm{~kg} \mathrm{~m}^{-3}$ for irrigated vs. $0.85 \mathrm{~kg} \mathrm{~m}^{-3}$ for non-irrigated treatment. As the sowing date is delayed, total water productivity decreased while the irrigation water productivity increased. For sowings made during the recommended sowing window, grain water use efficiency of faba bean is commonly in the range of $0.8-1.2 \mathrm{~kg} \mathrm{~m}^{-3}$. For very late sown crop, this drops to $0.4-0.6 \mathrm{~kg} \mathrm{~m}^{-3}$ [34].

\subsection{Response to Irrigation}

The response of faba bean to irrigation is shown in Figure 12 in terms of the CC, AGDM, and TSW of late-May sown irrigated and dryland faba bean. The observed data from the two-year field experiment indicate that the average grain yield for the non-irrigated treatments was $2.7 \mathrm{t} \mathrm{ha}^{-1}$, while the yield from the irrigated treatments was $4.7 \mathrm{t} \mathrm{ha}^{-1}$, a $75 \%$ yield increase. Irrigation of early sown faba bean increased yield by $47 \%$, while irrigation of late sown faba bean increased the yield by $108 \%$. This indicates that irrigation has greater effect on the late sown faba bean than on the early sown faba bean. If not irrigated, the flowering, pod-forming, and pod-filling stages of late sown faba bean can be exposed to moisture stress. In Southern Australia, to maximise yield potential, faba bean should be watered during the spring (flowering and pod-filling) period and not allowed to stress. As shown by a higher water productivity in Figure 11, spring-irrigated faba bean showed higher yield-response to irrigation compared to irrigation at other growth stages, indicating the importance of the timing of irrigation.
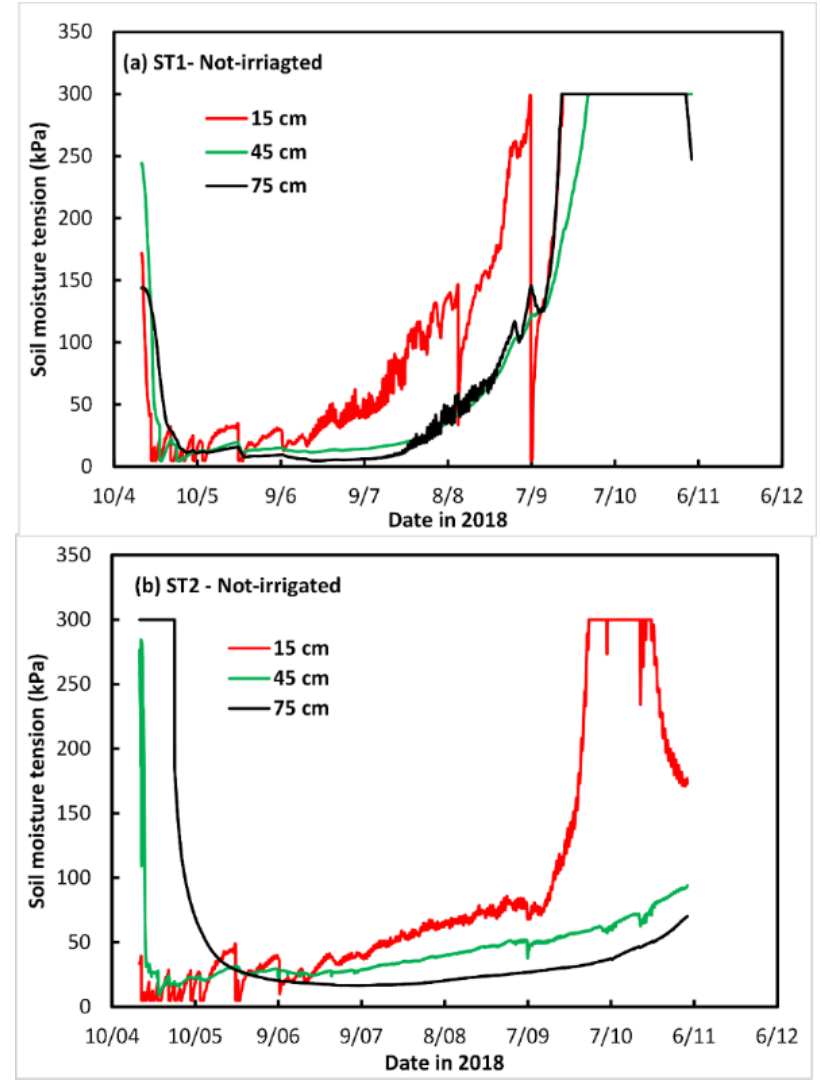

Figure 10. Soil water tension for an early sown and late sown faba bean as monitored using gypsum blocks installed at three depths in the root zone. 


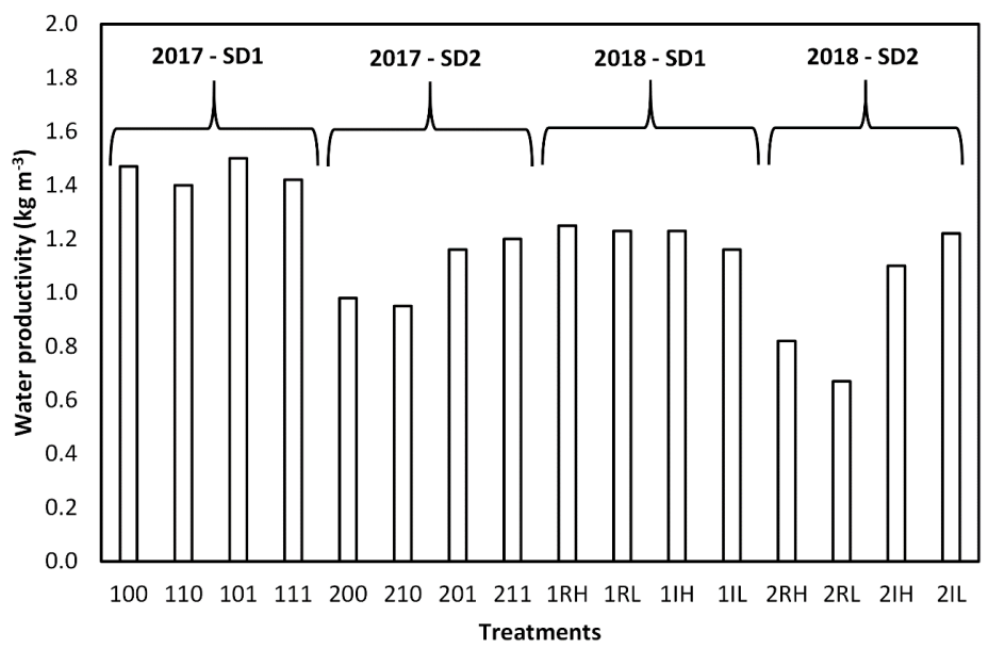

Figure 11. Water productivity (grain yield/evapotranspiration) of faba bean as affected by sowing time, watering regime, and sowing rate.
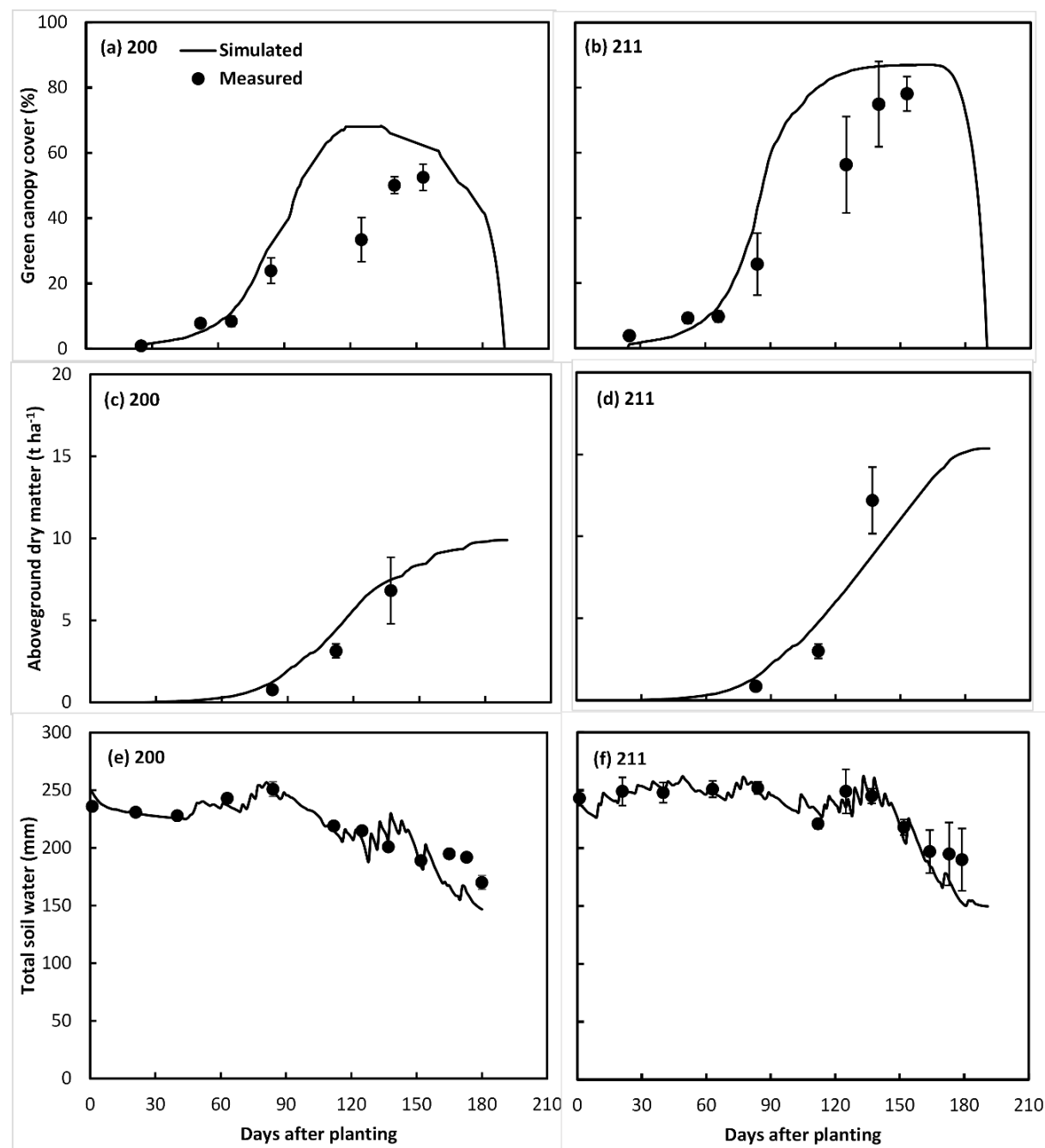

Figure 12. Measured and simulated green canopy cover (CC), above-ground dry matter (AGDM) and total soil water (TSW) for a late sown un-irrigated (200) and irrigated (211) faba bean. (a) Measured and simulated CC for 200; (b) measured and simulated CC for 211; (c) measured and simulated AGDM for 200; (d) measured and simulated AGDM for 211; (e) measured and simulated TSW for 200; (f) measured and simulated TSW for 211. 
As shown in Figure 12 and Table 3, AquaCrop has adequately simulated the response of faba bean to irrigation as indicated by the close agreement of measured and simulated values of AGDM and TSW. It overestimated the measured CC during the crop growth stage. AquaCrop has correctly simulated the effect of irrigation on CC, with irrigated treatment having maximum CC $80 \%$ and unirrigated treatment having only $60 \%$ maximum CC. Since the data shown in Figure 12 are from the late sown treatment, the crop stayed at the maximum canopy stage only for a short period. However, the irrigated treatment has reached the maximum canopy level that was equivalent to the early sown irrigated treatment, although it remained at that level only for a relatively short period. In years with adequate winter rainfall, irrigation should be avoided before flowering, as this can result in tall, vegetative, disease-prone, and low-yielding crops. However, if winter rainfall is not adequate, first spring irrigation needs to be applied early to prevent moisture stress impacting on flowering, grain yield, and grain size [33].

\subsection{Effect of Sowing Rate}

The measured and simulated CC, AGDM, and TSW at two sowing rates (21 plants $\mathrm{m}^{-2}$ and 39 plants $\mathrm{m}^{-2}$ ) are shown in Figure 13. As can be seen in Figure 12 and Table 3, AquaCrop correctly simulated the measured CC, AGDM, and TSW values. Measured maximum CC was $84 \pm 4 \%$ and $86 \pm 3 \%$, for low and high sowing rates, respectively, while the simulated maximum CC was $84 \%$ for both low and high sowing rates. Measured AGDM for the low and high sowing rates was $12.8 \pm 0.1 \mathrm{t} \mathrm{ha}^{-1}$ and $12.1 \pm 0.5 \mathrm{tha}^{-1}$, respectively, while the simulated AGDM was $13.5 \mathrm{tha}^{-1}$ and $13.7 \mathrm{t} \mathrm{ha}^{-1}$, respectively. Measured end-of-season TSW was $179 \pm 20 \mathrm{~mm}$ and $174 \pm 6 \mathrm{~mm}$, respectively, and the simulated end-of-season TSW was $155 \mathrm{~mm}$ and $156 \mathrm{~mm}$, respectively. From these results, it can be seen that both measured data and AquaCrop simulation show no significant difference between the two sowing rates. For rainfed corn, Martini [35] showed that AquaCrop is less sensitive to crop management factors such as planting density.

According to GRDC [1], faba bean plant population requirements depend on the time of sowing. Higher population is used for late sown crop, to compensate for lower branching and flowering sites. However, Matthews et al. [33] indicated that under favourable conditions, faba bean yield is not significantly affected over a wide range of plant populations, since sparser plants grow more vigorously and fill any gap in plant rows. A 20-35 plants $\mathrm{m}^{-2}$ and 20-30 plants $\mathrm{m}^{-2}$ have been acceptable plant densities in dryland and irrigated Southern NSW [33]. In dryland Southern Australia, plant density of 30 plants $\mathrm{m}^{-2}$ is generally recommended [34]. In this study, increased sowing rate for late-sown faba bean did not increase yield (Table 3). This is probably due to the sowing rate being not much higher than the recommended range. For faba bean (cv. Samira) sown at 30, 40, and 50 plants per $\mathrm{m}^{-2}$ in April and May, no significant yield difference was found between the 30 and 40 plants $\mathrm{m}^{-2}$ treatments, while there was significant difference between the yields of 30 and 50 plants $\mathrm{m}^{-2}$ treatments [36]. 

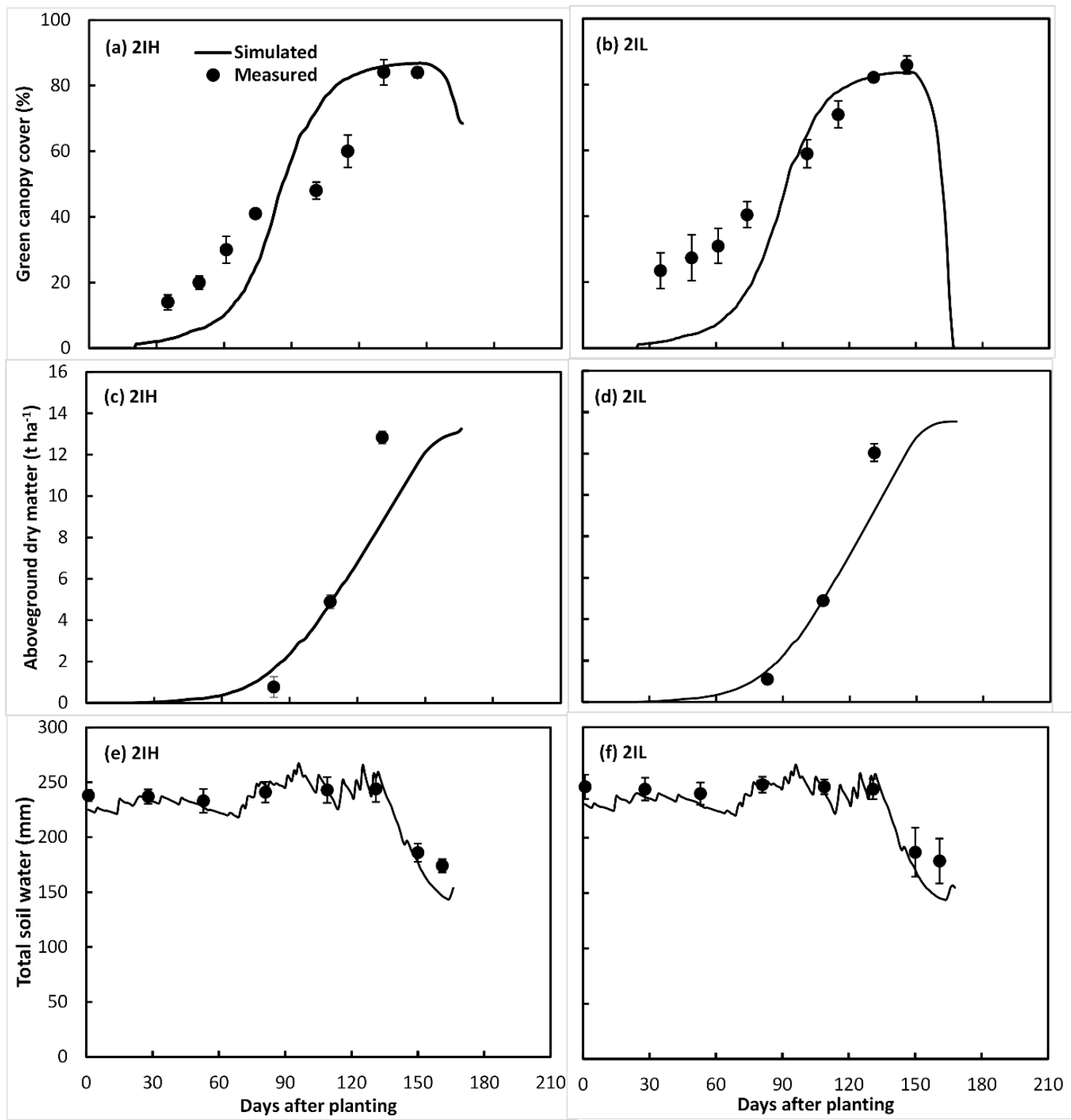

Figure 13. Measured and simulated green canopy cover (CC), above-ground dry matter (AGDM), and total soil water (TSW) for high and low sowing rates. (a) Measured and simulated CC for 2IH; (b) measured and simulated CC for 2IL; (c) measured and simulated AGDM for 2IH; (d) measured and simulated AGDM for 2IL; (e) measured and simulated TSW for 2IH; (f) measured and simulated TSW for 2IL.

\section{Conclusions}

AquaCrop was able to predict the impacts of different management decisions on crop growth, yield, and resource use reasonably well. The model predicted crop yield with acceptable accuracy (deviation $=3 \%, \mathrm{R}^{2}=0.86, d=0.95$, RMSE $=0.49 \mathrm{tha}^{-1}$, and NRMSE of $12.4 \%$ ). From the results of this study, it is possible to suggest that AquaCrop could be used to predict crop growth, grain yield, water productivity, and soil water dynamics with a reasonably high degree of confidence for various sowing dates, irrigation management strategies, and sowing rates. AquaCrop correctly simulated the effect of supplemental irrigation, sowing date, and sowing rate on yield. In South-Eastern Australia, the recommended sowing dates are from third week of April to second week of May. Sowing in late May decreased grain yield by $36 \%$ and should be avoided when possible. It could be concluded that AquaCrop can be a useful tool to help decision making for faba bean irrigation 
management and evaluation of different sowing dates and rates to maximise yield. The application of the parameters determined in this study need to be tested for different faba bean cultivars, environments and management scenarios.

Funding: This research was funded by Graham Centre for Agricultural Innovation (Charles Sturt University and NSW Department of Primary Industries).

Conflicts of Interest: The authors declare no conflict of interest.

\section{References}

1. Grains Research and Development Cooperation. Faba Bean Southern Region-GrowerNotes; Grains Research and Development Cooperation: Canberra, Australia, 2017; Available online: https://grdc.com.au/re sources-and-publications/grownotes/crop-agronomy/faba-bean-southern-region-grownotes (accessed on 22 February 2019).

2. Zong, X.; Liu, X.; Guan, J.; Wang, S.; Liu, Q.; Paull, J.G. Molecular variation among Chinese and global winter faba bean germplasm. Theor. Appl. Genet. 2009, 118, 971-978. [CrossRef] [PubMed]

3. Garofalo, P.; Di Paolo, E.; Rinaldi, M. Durum wheat (Triticum durum Desf.) in rotation with faba bean (Vicia faba var. minor L.): Long-term simulation case study. Crop Past. Sci. 2009, 60, 240-250. [CrossRef]

4. Di Paolo, E.; Garofalo, P.; Rinaldi, M. Irrigation and nitrogen fertilization treatments on productive and qualitative traits of broad bean (Vicia faba var. minor L.) in a Mediterranean environment. Legume Res. 2015, 38, 209-218. [CrossRef]

5. Siddiqui, M.H.; Al-Khaishany, M.Y.; Al-Qutami, M.A.; Al-Whaibi, M.H.; Grover, A.; Ali,H.M.; Al-Wahibi, M.S.; Bukhari, N.A. Response of Different Genotypes of Faba Bean Plant to Drought Stress. Int. J. Mol. Sci. 2015, 16, 10214-10227. [CrossRef] [PubMed]

6. Mebrahtu, G.; Walelign, W.; Woldeyesus, S. Effect of Integrated Crop-Management Packages on Yield and Yield Components of Faba Bean (Vicia faba L.) cultivars in Southern Ethiopia. Vegetos Int. J. Plant Res. 2018, 31, 146-157. [CrossRef]

7. Bishop, J.; Potts, S.G.; Jones, H.E. Susceptibility of faba bean (Vicia faba L.) to heat stress during floral development and anthesis. J. Agron. Crop Sci. 2016, 202, 202-508. [CrossRef] [PubMed]

8. Flores, F.; Nadal, S.; Solis, I.; Winkler, J.; Sass, O.; Stoddard, F.L. Faba bean adaptation to autumn sowing under European climates. Agron. Sustain. Dev. 2012, 32, 727-734. [CrossRef]

9. Adisarwanto, T.; Knight, R. Effect of sowing date and plant density on yield and yield components in the faba bean. Aust. J. Agric. Res. 1997, 48, 1161-1968. [CrossRef]

10. Villalobos, F.J.; Orgaz, F.; Fereres, E. Sowing and Planting. In Agronomy for Sustainable Development; Villalobos, F., Fereres, E., Eds.; Springer: Cham, Switzerland, 2016.

11. Keating, B.A.; Carberry, P.S.; Hammer, G.L. An overview of APSIM, a model designed for farming systems simulation. Eur. J. Agron. 2003, 18, 267-288. [CrossRef]

12. Jones, J.W.; Hoogenboom, G.; Porter, C.H.; Boote, K.J.; Batchelor, W.D.; Hunt, L.A.; Wilkens, P.W.; Singh, U.; Gijsman, A.J.; Ritchie, J.T. The DSSAT cropping system model: Modelling cropping systems: Science, software and applications. Eur. J. Agron. 2003, 18, 235-265. [CrossRef]

13. Falconnier, G.N.; Journet, E.P.; Bedoussac, L.; Vermue, A.; Chlébowski, F.; Beaudoin, N.; Justes, E. Calibration and evaluation of the STICS soil-crop model for faba bean to explain variability in yield and $\mathrm{N} 2$ fixation. Eur. J. Agron 2019, 104, 63-77. [CrossRef]

14. Ruiz-Ramos, M.; Mínguez, M.I. ALAMEDA, a structural-functional model for faba bean crops: Morphological parameterization and verification. Ann. Bot. 2006, 97, 377-388. [CrossRef] [PubMed]

15. Hassanein, M.K.; Medany, M.A.; Haggag, M.E.; Bayome, S.S. Prediction of yield and growth of faba bean using CROPGRO legume model under egyptian conditions. Acta Hort. 2007, 729, 215-219. [CrossRef]

16. Boote, K.J.; Mínguez, M.I.; Sau, F. Adapting the CROPGRO legume model to simulate growth of faba bean. Agron. J. 2002, 94, 743-756. [CrossRef]

17. Raes, D.; Steduto, P.; Hsiao, T.C.; Fereres, E. AquaCrop-The FAO crop model to simulate yield response to water: II. Main algorithms and software description. Agron. J. 2009, 101, 438-447. [CrossRef]

18. Bello, Z.A.; Walker, S. Calibration and validation of AquaCrop for pearl millet (Pennisetum glaucum). Crop Pasture Sci. 2016, 67, 948-960. [CrossRef] 
19. Trombetta, A.; Lacobellis, V.; Taranito, E.; Gentile, F. Calibration of the AquaCrop model for winter wheat using MODIS LAI images. Agric. Water Manag. 2016, 164, 304-316. [CrossRef]

20. Nyathi, M.K.; van Halsema, G.E.; Annandale, J.G.; Struik, P.C. Calibration and validation of the AquaCrop model for repeatedly harvested leafy vegetables grown under different irrigation regimes. Agric. Water Manag. 2018, 208, 107-119. [CrossRef]

21. García-Vila, M.; Fereres, E.; Mateos, L.; Orgaz, F.; Steduto, P. Deficit irrigation optimization of cotton with AquaCrop. Agron. J. 2009, 101, 477-487. [CrossRef]

22. Heng, L.K.; Hsiao, T.; Evett, S.; Howell, T.; Steduto, P. Validating the FAO AquaCrop Model for Irrigated and Water Deficient Field Maize. Agron. J. 2009, 101, 488-498. [CrossRef]

23. Abrha, B.; Delbecque, N.; Raes, D.; Tsegay, A.; Todorovic, M.; Heng, L.; Vanuytrecht, E.; Geerts, S.; Garcia-Vila, M.; Deckers, S. Sowing strategies for barley (Hordeum vulgare L.) based on modelled yield response to water with AquaCrop. Exp. Agric. 2012, 48, 252-271. [CrossRef]

24. Zeleke, K.T.; Luckett, D.; Cowley, R. Calibration and testing of the FAO AquaCrop model for canola. Agron. J. 2011, 103, 1610-1618. [CrossRef]

25. ApSoil. A Database of Soil Characteristics. 2013. Available online: http://www.apsim.info/Products/APSoil.a spx (accessed on 15 January 2019).

26. Pulse Australia. PBA Samira Faba Bean. Southern Region. Pulse Australia. 2014. Available online: http://pulseaus.com.au/storage/app/media/crops/2014_VMP-Fababean-PBASamira.pdf (accessed on 12 March 2019).

27. Perry, E.M.; Fitzgerlad, G.J.; Poole, N.; Craig, S.; Whitlock, A. Ndvi from active optical sensors as a measure of canopy cover and biomass. In International Archives of the Photogrammetry, Remote Sensing and Spatial Information Sciences; ISPRS Congress: Melbourne, Australia, 2012; p. 8.

28. Steduto, P.; Hsiao, T.C.; Raes, D.; Fereres, E. AquaCrop-The FAO crop model to simulate yield response to water: I. Concepts and underlying principles. Agron. J. 2009, 101, 426-437. [CrossRef]

29. Allen, R.G.; Pereira, L.S.; Raes, D.; Smith, M. Crop Evapotranspiration. Guidelines for Computing Crop Water Requirements; Irrigation and Drainage Paper No. 56; FAO: Rome, Italy, 1998.

30. Willmott, C.J. Some comments on the evaluation of model performance. Bull. Am. Meteorol. Soc. 1982, 63, 1309-1313. [CrossRef]

31. Steduto, P.; Hsiao, T.C.; Fereres, E. On the conservative behaviour of biomass water productivity. Irrig. Sci. 2007, 25, 189-207. [CrossRef]

32. Richards, M.; Armstrong, E.; Gaynor, L.; Graham, N.; Coombes, N. Sowing Time and Variety Selection for Faba Bean in Southern NSW. Grains Research and Development Cooperation GRDC. 2016. Available online: https:/grdc.com.au/resources-and-publications/grdc-update-papers/tab-content/grdc -update-papers/2016/02/sowing-time-and-variety-selection-for-faba-bean-in-southern-nsw (accessed on 17 March 2019).

33. Matthews, P.; McCaffery, D.; Jenkins, L. Winter Crop Variety Sowing Guide 2017; NSW Department of Primary Industries: Sydney, Australia, 2017.

34. Pulse Australia. Faba Bean Production: Southern and Western Region. Pulse Australia. 2016. Available online: http:/www.pulseaus.com.au/growing-pulses/bmp/faba-and-broad-bean/southern-gu ide\#general-agronomy (accessed on 17 March 2019).

35. Martini, L.C.P. Sensitivity analysis of the AquaCrop parameters for rainfed corn in the South of Brazil. Pesq. Agropec. Bras. 2018, 53, 934-942. [CrossRef]

36. Gebert, C.; Midwood, J. Faba Bean Agronomy. Southern Farming System. 2016. Available online: http://www.sfs.org.au/trial-result-pdfs/Trial_Results_2016_VIC/5.7\%20Faba\%20bean\%20agronomy.pdf (accessed on 12 April 2019).

(C) 2019 by the author. Licensee MDPI, Basel, Switzerland. This article is an open access article distributed under the terms and conditions of the Creative Commons Attribution (CC BY) license (http://creativecommons.org/licenses/by/4.0/). 